\title{
Theory of Organizations: New Answers to Old Questions
}

\author{
Aurel Burciu and Rozalia Kicsi \\ Ștefan cel Mare University of Suceava, Romania
}

Correspondence should be addressed to: Aurel Burciu; aurelb@usv.ro

Received date: 1 February 2016; Accepted date: 13 June 2016; Published date: 8 September 2016

Academic Editor: Roxana-Mihaela Sirbu

Copyright (C 2016. Aurel Burciu and Rozalia Kicsi. Distributed under Creative Commons CC-BY 4.0

\begin{abstract}
The questions regarding the optimum organization of a company have gripped an increasing interest of academicians in the mainstream economics. A growing body of literature concerning the nature of the firm has filled a real niche both in the register of macroeconomic approaches, and in that of microeconomic approaches. But the old paradigms seem to be inadequate to explain the new challenges, particularly in the context of the profound transformations which reconfigures the nowadays economy. On this background, our study proposes a model of the knowledge - based firm and business networks. In essence, we believe that an optimum model for business organization could be designed through an assertion of the core principles of management, which would provide the basis for competition and cooperation between the different categories of companies. Such a model opens up new research directions where the classical and neoclassical economics seem to have depleted their answers.
\end{abstract}

Keywords: organizations theory, transaction cost, knowledge-based firm, business networks

\section{Introduction}

The global economic crisis (of the end of 2000s) surprised the entire world by its intensity, contagion, and economic and social consequences. For the first time, economists have begun to compare the current period of crisis with the Great Depression of the '30s (Roubini, 2011; Krugman, 2009). Study of business cycles, the relationship between the capitalist state and business world, monetary policies of central banks and other similar topics suddenly became much debated. In fact, we can say that the old dispute between Keynes's view (who claimed direct state intervention in the economy through investment, monetary policies and other instruments) and Hayek's view (who believed that government intervention is an error and that only the market can restore the economic balance) returns in economic theory; it is difficult to say which of the two views are more suitable to be considered by policymakers today (Hayek, 1933; Keynes, 1973; Keynes, 2009). In an attempt to diminish the effects of the global crisis and mitigate its social consequences 
(bankruptcies, unemployment, panic spread over large social groups, loss of income, etc.), states have adopted different measures from one case to another. Most economists agree that during a moderate recession or even a severe economic crisis, the capitalist state must react through adopting appropriate macroeconomic strategies to limit the social effects of such economic phenomena. But there is no theoretical model to be followed by the state and by companies to get out of a deep recession. In other words, the behaviour of large social groups and the reaction of firms during a recession or a crisis requires new theoretical analysis. This is because the realities of the world in which we live (with its main characteristics: technical/technological factors, computer networks, EU integration processes, interdependence between individuals and organization, education, scientific research, knowledge as a distinct resource, etc.) differ fundamentally from the realities over seven or eight decades ago. Furthermore, economists have been forced to accept the idea that the current economic crisis reveals the need for reconsideration/redefinition of classical views in economic theory. Among such issues, we believe, the theory of the firm gains more importance in scientific and empirical research; however, the classical economic theory provides only a few answers on this subject.

In our point of view, approaches of the theory of the firm can be differentiated to some extent, depending on the perspective in which it was located by authors:

- Studies on the nature of the firm from a macroeconomic perspective (emphasizing market and resource allocation mechanism to outline a theoretical model of the firm);

- Opinions and studies on the theory of organization predominantly from a microeconomic perspective (the emphasis is on rules/management principles applied by firms that tend to excellence or peak performance; we understand that the description of such rules may provide an answer to the theory of firm, meaning that other less efficient firms will be inspired by the model described).

\section{Macroeconomic view on the nature of firm}

During more than two centuries of economic theory, from The Wealth of Nations by Adam Smith (1776), economists have failed to fully and concisely answer the question "What is the optimal/ ideal model for organizing a business?". We understand a firm like any type of economic "actor" (enterprise, company, corporation, etc.) acting/performing in a competitive environment; this means that economic resources are allocated through the market mechanism, in terms of competition. In connection with the previous question, we could formulate another question: "What kind of management leads to performance?"; in other words, which are the principles/rules to be applied by the owners/managers to achieve success in business?

Given the very large diversity in which we can find companies in business environment (by sectors, by activity, by size, etc.), we believe it is extremely difficult to "cover" a diverse reality through a single abstract model of firm (Anderson et al., 2002). And if this diverse reality cannot be simplified enough to be included in a single theoretical model, then, as Lipsey stated, economists would require dozens of different theories or even "... a theory for each type of company ", in which, perhaps, it would reach some consensus on this topic (Lipsey, 1990: 177). In the capitalist economy, during a turbulent period a company can reach bankruptcy, which means negative consequences for the owners, employees, banks, and other interest groups (stakeholders) (Cooper, 2005).

Any company has two "dimensions" which are in a deep interdependence:

- The human dimension, namely managers, employees, including various types of knowledge like know-how;

- The material dimension, i.e. buildings, equipment and other tangible assets. 
It is noticeable that the various approaches or studies focusing on macroeconomic perspective have attempted to explain how a company strengths its position in a given market. As mentioned before, certain elements of external environment of the company (such as market, competition, industry, government strategies, macroeconomic trends, etc.) are largely generated by the specific of capitalist economy. Therefore, the founders and/or managers of a company cannot manage (possibly only to a minor extent) the external factors of a company that could affect the flow of business. The current global crisis shows that even corporations with a history of a century or more may go bankrupt (e.g. Lehman Brothers, Freddie Mac in the USA, etc.), due to an increased competition and instability in the business environment; the lifespan and average longevity of global corporations tends to decline in the last three or four decades (de Geus, 1999). Also, due to a deeper interdependence between countries, companies and economic sectors, some technological, social or market trends amplify uncertainty and volatility/chaos of the environment in which companies emerge and develop (Kotler and Caslione, 2009). However, many large companies, but also some of those in the small business sector, managed to overcome the crisis from 2008 to the present and even to identify opportunities in a chaotic environment of business (Kotler and Caslione, 2009). How is this situation, statistically confirmed in the US, but also in some European countries, explained? Which one would be the optimal corporate model today?

During the past decades, the literature on the types of companies and the role of entrepreneurs in the capitalist economy shows a variety of approaches. Some authors discuss about industrial enterprise, and mainly about the relationship between costs of such an organization, the importance of entrepreneurs and performance obtained (Hay \& Morris, 1986). Like these authors, we agree on the fact that only individuals can propose goals and achieve them. Other authors highlight the importance of the human factor in any type of organization. As Galbraith states, "in any large organization, above all else, there must be a highly developed sense of common purpose" (Galbraith, 1921, p. 67).

After the Great Depression of '29 -'33, a growing body of literature has focused on the theory of the firm from various points of view. (Anderson et al., 2002). Some "atypical" views were initially ignored, as was the Coase's ideas about the nature of the firm. He proposes - as expressed - $a$ realistic and innovative theory to tackle the apparent contradiction between resource allocation through price mechanism and the role of the entrepreneur in a competitive economy (Coase, 1937). In his most notable and ground-breaking work, The Nature of the Firm, Coase developed the concept of transaction costs; the costs of organizing a specific activity vary from one company to another, so a firm enters in a market as long as its operational costs are lower than the similar costs of other firms or those related to market transactions (Coase, 1937). We believe that in order to achieve lower transaction costs, certain rules/principles of management have to be applied within the company. So, the focus on microeconomic perspective could explain the way any business organization can gain and strengthen its position in certain markets (Coase, 1937).

Another noticeable point of view belongs to Williamson; based on Coase's concept of transaction costs, he focuses on the organization of production, transaction costs, vertical integration of production in certain sectors, the behaviour of "actors" in business environment, i.e. entrepreneurs and employees, etc. (Williamson, 2010). We believe that the main Williamson's contribution to the theory of the firm lies in the fact that it raises new questions (Williamson, 2010): "What is the size to which a firm can increase in a certain market?"; ""How do operating costs evolve with the increasing of specific hierarchical bureaucracy in any company?". Yet, we don't have coherent answers to such questions, so that further research/approach in the theory of the firm is desirable. 


\section{Developments in the theory of organizations: microeconomic view}

We want to emphasize that the emerging of an enterprise and strengthening its position in a certain market cannot be fully explained without taking into account the company principles of management. This is because any type of firm must manage a certain amount of "operating" costs to achieve its long-term goals. Today, it is quite widely accepted the idea that investors, founders or managers of any company should have a moral behaviour when allocating resources to establish a new company; the achievement of company goals should sustain the achievement of the common interest, so it goes beyond managing costs and gaining profit.

In order to open some new areas in the theory of the firm we can follow a parallel view to those of Coase (1937), Williamson (2010) and other authors on this topic. In other words, it would be desirable to be able to state a core set of rules/principles for an ethical management, which could be a "model" of gaining performance for any company.

We will briefly bring to the fore some views enshrined in practice of business economics which may provide some answers in the theory of the firm.

In the theory and practice of business organizations a distinct, coherent, and very pertinent point of view belongs to Peter Drucker and it has been developed about six decades ago, starting with his works Concept of the Corporation (1946), The Practice of Management (1954), etc. After a comprehensive study on General Motors Corporation (on the constitution, internal organization, structure, key principles applied in daily practice, divisional organization and decentralization of power, the adaptability of the company in an unstable business environment etc.), Drucker lays down certain rules/principles of management that became later an "organizational model" for other companies, government agencies, universities and other organizations
(Drucker, 1946). Later, the author proposed the concept of management by objectives and self-control (MBO) as a principle that should underpin the internal organization of any company. Essentially, an MBO program starts by negotiating objectives from the CEO to the bottom, at all levels, reaching, if possible, to every employee (Drucker, 1954). Therefore, we conclude that any employee who voluntarily accepts certain annual targets will be by default self-motivated to achieve maximum performance in their daily work (i.e. company's operating costs lower than other competitors, etc.). Finally, Drucker made over time other valuable opinions about the mission of the company, the market in which it operates, the knowledge economy, etc.; between such views we mention (Drucker, 2001; Drucker, 2002; Drucker, 2008):

- The purpose of a company should be sought in society and refers to the common interest, in the sense that the company should add social value by products/services performed;

- Gaining profit is just a condition for the lucrative company and not an end in itself (companies must comply ethics / moral rules imposed by society);

- Performing firms tend to control the entire value chain of a product/service, so to cooperate in the context of competition for customers (organizing alliances/partnerships strategic alliances after the keiretsu model of Japanese firms practice);

- Knowledge has now become an essential resource for any business, and computer networks have become a major asset to jointly acquire and share this resource;

- Employees in a modern company must accept the idea of lifelong learning individuals and as members of a management team (lifelong learning).

Drucker's perspectives on the context in which a firm appears within a capitalist economy, as well as the ways in which it gets time performance, are quite broad. We 
conclude that the rules/principles of management underlying the capitalist company have a dynamic character and therefore change according to evolutions of the capitalist society. Secondly, it follows that any model in the theory of the firm must take into account the current realities of capitalist society; since the early 1980s to the present, computer networks have become a vector of social progress and, consequently, should be included as a constituent in the theory of the firm. Thirdly, we conclude that the capitalist state must "reinvent" itself to manage failures that occur in the market mechanism.

The concept of business excellence, proposed by Peters and Waterman (1982) is based on a survey of a sample of 43 highperformance companies, a study through which it was attempted to answer the question "What rules/principles of management apply in practice performing companies?" In fact, the authors develop a model of the ideal firm; moreover, if we can answer pertinently the question raised, we can then generalize those rules/principles. Following the study, Peters and Waterman concluded that there are eight management principles that lead to business performance in the capitalist economy (creating a favourable climate for quick action, the company is targeting customers and their needs, new ideas from employees are encouraged, business innovation is used simultaneously with decentralization of powers, members of the organization share common values and are selfmotivated in the daily work etc.) (Peters \& Waterman, 1982). If we generalize the conclusions of the two authors, we can say that there are eight rules, which we can note R1, R2, ..., R8, which can be implemented by companies outside the reference sample; these rules can become a guide and/or a "model" for other firms in any capitalist economy (Burciu, 1999). Among other findings, we conclude that firms that tend to excel in their field get lower operating costs compared to other competitors (in time was found, however, that such firms can withstand only a limited time as part of the performance sample; therefore, any model in the theory of the firm has a dynamic character).

Another concept, namely the reengineering of the company, argued by Hammer and Champy (1993) proposes certain criteria for establishing / redesigning of a business, starting from the "white sheet"; businesses, say the two authors, should be designed based on processes and not on the basis of separate operations, which would increase the company's performance by $100 \%$ (Tacu, 1998; Hammer, and Champy, 1993). More specific, the concept of reengineering of a firm places knowledge and computer networks at the centre of the proposed criteria for setting/redesigning a company (when the company is already in a market, decision makers can redesign the entire organizational structure based on processes by leveraging advantages brought by IT and knowledge revolution) (Tacu, 1998; Hammer, and Champy, 1993). Theoretically, if a newly established company and / or an existing one on the market increases its performance by $100 \%$ compared to the average of its domain, it would, consequently, lead to a major reduction in operating costs. Among the various advantages that the computer brings is the exploitation of knowledge as a distinct resource for any business (applying one Business Process Reengineering -BPR), we mention the following (Hammer \& Champy, 1993):

-Information/knowledgeoccurs
simultaneously in as many places as
needed in the structure of the company;

- A general employee can perform the work of an expert (to some extent);

- The advantages of centralizations and descentralization of competencies can be simultaneously harness;

- Decision-making is part of the duties of each employee;

- Staff in the field can transmit and receive information/knowledge wherever they are.

So, this concept of BPR suggests some principles of management applied on the 
basis of which a company can significantly reduce operating costs through processbased organization of all activities within its structure (about the product / service, technology used, market and management structures).

Finally, the so-called "holonic firm/network" can be, in our opinion, another contribution to the foundation of the theory of the firm. This concept of holonic company was proposed by Mc.Hugh and other authors in the field of theory of organizations; it constitutes a kind of extension of the concept of our previously mentioned BPR (Mc.Hugh et al, 1995). When a firm achieves the status of "excellence" in its activity (whether or not it applies a BPR program), it can opt for the establishment of strategic alliances with other firms in the industry; all $n$ companies must take into account the wishes of their common customers and can propose adding social value to products/services developed. In other words, holonic networking must not be motivated by getting extra profit; on the contrary, such networks should target the common good and the fulfilment of social responsibility (Corporate Social Responsibility) (Drucker, 2008). However, through the joint exploitation of new knowledge, extensive use of computer networks and by creating strategic partnerships of "holonic network", companies can reduce their operating costs. (McHugh et.al, 1995). In fact, we believe that the concept of holonic firm/network approaches clearly the Drucker's idea about controlling the entire value chain of a product/service for businesses and consumers to obtain mutual benefits (Drucker, 2001). In other words, different theoretical developments often reach a common point in trying to propose / suggest some management rules/principles that can be applied by a company to strive for optimal model of organization of a business.

Among other findings, we conclude that there are multiple approaches to microeconomic theory of the emergence and consolidation of modern organizations from different markets; we believe that only a synthesis of different opinions mentioned can support us in trying to build a model of optimal firm. However, we believe that modern capitalist state today should be included in any theoretical construction regarding the optimal model of the firm; companies are required to accept the idea of building a moral capitalism (Young, 2003), and this goal cannot be conceived without the active role of the state/government.

\section{The need for a new approach: knowledge-based model of the firm}

One of the recent developments in the theory of the firm is called knowledge-based firm, in which case theorists believe that what we call knowledge plays a major role in explaining how a company appears on the market and how it strengthens its position in time. In other words, this theoretical concept considers that various questions in the theory of the firm (its existence, transaction costs, organization and management applied, the performance obtained, etc.) can be adequately explained on account of knowledge as a resource exploited by business organizations. The concept of knowledge-based firm has occurred in economic theory recently, with the establishment of what we call the knowledge economy /society; more precisely, since the 80 s, several areas were highlighted in theory, such as KM (knowledge management), LO (learning organization), etc. The concept of the $\mathrm{LO}$ is argued mainly by Peter Senge (2006) and is based on certain courses of action for decision makers in any firm to establish lifelong learning for individuals and per organization (mental models applied, common vision of the company, team learning, etc.). In the $\mathrm{KM}$, a distinction is made between explicit knowledge (those found in textbooks, books, etc.) and tacit knowledge (those obtained through direct experience and practical skills). An extremely popular topic in KM is the SECI model (Socialization, Externalization, Combination and Internalization) which explains the mechanism of conversion of tacit knowledge into explicit and vice versa. From this perspective, we understand that explicit knowledge is available to all employees and/or companies, while tacit 
knowledge is highly personal in nature; the latter depends on the ability and effort of each employee to learn, on KM and HRM strategies of the company, and also on the relationship between groups and teams of employees and other similar factors. In other words, we believe that any attempt to explain the emergence and consolidation of a company in a particular market should refer especially to tacit knowledge; particularly the quantity and quality of this kind of knowledge could explain different actions and performance of firms in the same sector and/or in different ones.

In the most general sense, one can say that any firm performs a particular product or service that should have value for customers, resorts to some technical process /technology, relates to a real market where there are other competitors and applies certain rules/principles of management. Ideally, the founders and/or managers of any company should aim at a long-term mission of the organization, identifying core competencies of the company and keeping in mind that any business organization must add value in the social sense (it is not sufficient managing operating/trading costs). An indirect argument about knowledge-based firm is the fact that in the OECD countries, since 2008, most new entrants have targeted knowledge-based industries and services (OECD, 2014). Therefore, we believe that various studies and developments in firm's theory will relate in the future directly or indirectly to the qualification of employees in companies and highly specialized knowledge that every business organization must have.

In our opinion, describing an optimal knowledge-based model of the firm should follow two tracks of study. Firstly, it can be said that any firm appears and consolidates in a given market when its founders or managers manage to identify a set of new tacit knowledge and also when it has qualified employees to exploit this set of knowledge into products / services required by customers. Theoretically, if such knowledge is identified, we can hope that the company will be able to have lower costs than other competitors in the development of a product / service desired by customers. Secondly, it can be said that the company appears on the market when the decision maker manages to identify new ways of combining explicit knowledge that exist and are known in society at a time. Intuitively, we understand that the distinction between the two lines of analysis in theory can be only methodological, whereas the separation of the two classes of knowledge is purely theoretical. In other words, also for identifying new ways of combining explicit knowledge, there is a need for skilled employees and their tacit knowledge available to them as individuals and management teams.

On the other hand, identifying a set of new tacit knowledge and/or new combinations of explicit knowledge may relate to the product/service developed by the company, the technology used, market analysis or management structures applied (in Figure bellow we separate the four issues of interest for any business organization).

Various studies on the knowledge-based firm theory relate directly to Coase and Williamson, who wrote on transaction costs and internal organization of a company; we conclude that this approach attempts to take into account both the macroeconomic perspective and the microeconomic theory of the firm (such studies emphasize the role of knowledge to improve the company's organizational structure, operation of hierarchy in the flowchart, relations between departments or groups of employees etc.) (Grant, 1996; Kirsimarja, and Aino, 2009). In our opinion, the model proposed by Nonaka and some authors analysing how to create knowledge remains of reference on this topic (they discuss several components of the model, namely: application of SECI process through dialogue and practice in the firm, senior management vision regarding the exploitation of knowledge; interorganizational context in which employees and corporate groups relate; assets of knowledge type; business relationship with the environment to create knowledge, etc.) (Nonaka, Toyama, and Nagata, 2000; 
Nonaka, and Toyama, 2002; Nonaka, and Toyama, 2005). It can be said that this last concept in the theory of the firm emphasizes very fair the subjectivity of decision makers of organizations on the creation of new knowledge, the relatively high cost of this process, the difficulties of transforming tacit knowledge in explicit and vice versa etc. However, we understand that any model in the theory of knowledge-based company has inevitably a dynamic character; from this point of view, we can suggest a framework to underpin knowledge-based companies (Figure 1).
From our research perspective, this general framework of the theory of the firm can contribute to joining the firm's two perspectives of analysis and some future developments on this topic.

As noted in the Figure bellow, the general framework proposed by us includes several elements (the values the managers believe in, the relationship between explicit-tacit knowledge, social capital, core competences, etc.) but we believe that certain relationships that occur between such elements are significant.

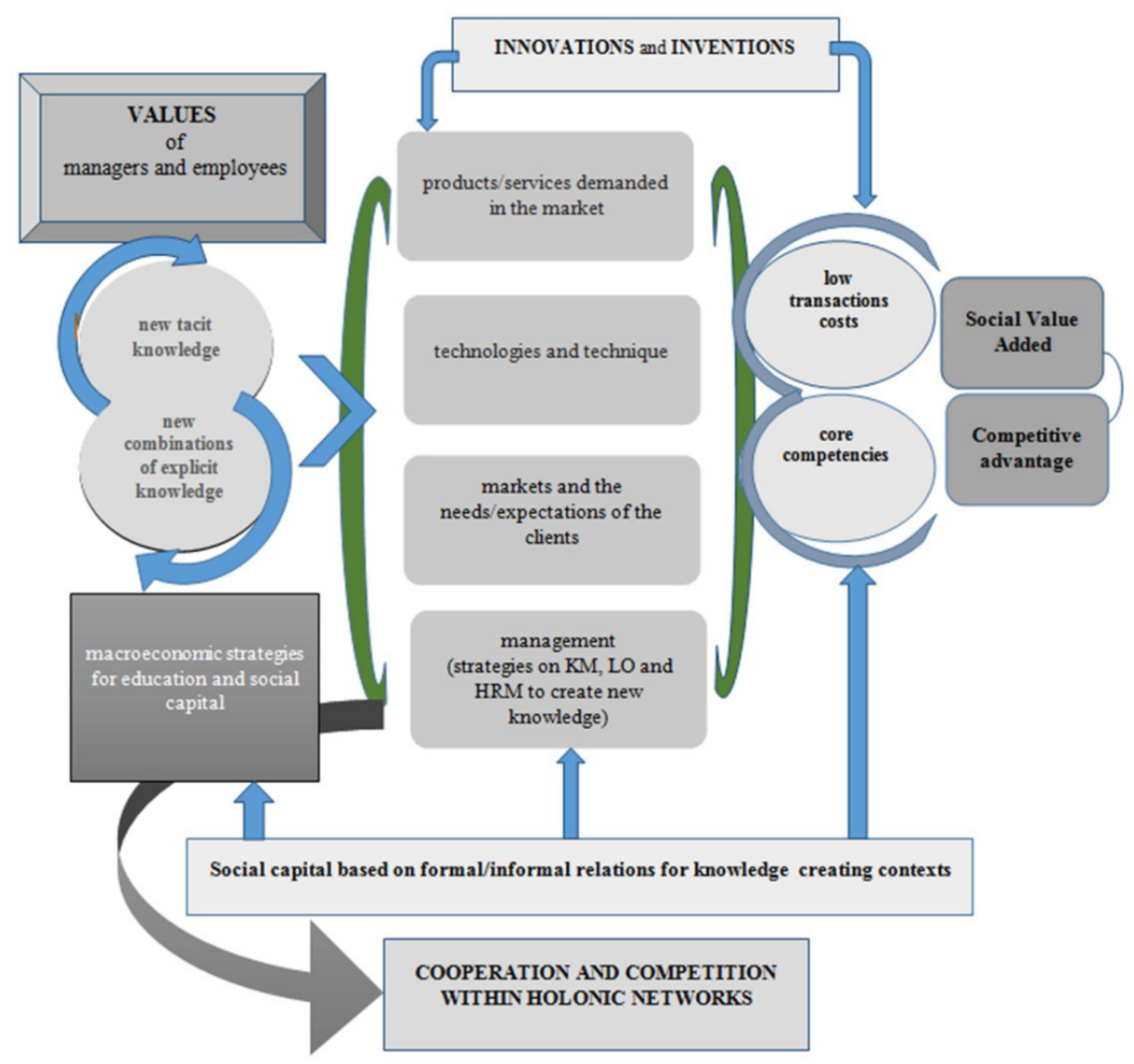

Figure 1: Knowledge-based model of the firm

Source: Authors' own conception

Aurel Burciu and Rozalia Kicsi (2016), Journal of Eastern Europe Research in Business and Economics, DOI:10.5171/2016.512584 
Every company should focus on identifying the new tacit knowledge and / or new combinations of explicit knowledge to impose on the market and meet the client needs/expectations. The premise from which founders/managers of a company start remains essential, we believe, in all economic theory; we believe that the value managers and employees of emerging market companies believe in will finally make the added value of the firm, i.e. fulfilling the mission proposed (the mission of any business organization should aim at the common good and not just getting profit).

Theoretically, it is sufficient for the firm to identify new knowledge and, respectively, innovations/inventions in any of the four specific aspects of an entity of such type (product/service, applied technologies, market and customers; rules/principles of management). We understand that it is ideal when the founders and/or managers are able to identify new knowledge and/or new ways of combining them on all four specific aspects of this type of organized structure. To remain on the market, the company must achieve permanent inventions/innovations meaning lifelong learning (LO) and distinct strategies in KM, HRM to create new knowledge continuously.

To be successful in a market, every company should have a long-term mission, which should aim at adding social value, that is, to make a small contribution to the social good. Since the modern capitalist economy now includes three major distinct sectors (corporate, social and the state's economy), the theory of the knowledgebased firm will develop in the future, we believe, with certain characteristics from one sector to another. In other words, accomplishing the firm's task on a long term remains conditioned by certain costs of operations (but the purpose of the company is to add value and cannot be reduced to management of costs).

Acquisition and processing of knowledge by a firm require relatively high costs, as well as qualified, motivated employees, willing to participate voluntarily in the permanent creation of new knowledge. Consequently, we need appropriate strategies in KM, HRM to minimize the cost per "unit" of newly created knowledge (piece of new knowledge or information) and, thus, to build "key skills" by any business organization.

The firm will minimize the annual operating costs to the extent that has appropriate strategies in KM, LO and HRM and manages to become a permanent entity that creates new knowledge. Fulfilling this conditionality should confer the firm a long-term competitive advantage. It is understood that the acquisition and permanent creation of new knowledge turns simultaneously into inventions/new innovations that enable decision makers to improve their key skills and, on this basis, to better respond to its customers' requirements.

It is the obligation of the capitalist state, we believe, to build appropriate macroeconomic strategies to support individual education, lifelong learning and social capital to support the production of new knowledge in all social groups. Perhaps the most important contribution of government to new firms in the corporate sector lies in the social climate networks based on trust and formal/informal intensive exploitation of existing knowledge in society (by default, it supports the conversion of tacit and explicit knowledge and the SECI model).

A key element that would play an important role in the theory of the firm is given by the values in which founders, managers and employees of any business organization believe. Such values are important in the very first attempt to identify new knowledge (tacit-explicit) and are associated with subjectivity in the process of creation/operation of knowledge; including the context in which employees interrelate to share knowledge. SECI model of operation and other issues in KM can be explained on account of values in which members of the organization believe (Nonaka et. al, 2000, 2002, 2005). 
Moreover, the values remain essential in capitalist society to build formal/informal networks and a social capital to foster economic performance (the distinction between good and evil, right and wrong, the redistribution of income, by the state, between social groups, social protection for certain people or families etc.).

In our opinion, a distinct element of the overall framework in knowledge-based firm theory is given by the relationship between any company and state/government since the modern capitalist state influences the market through many direct/indirect instruments. Therefore, macroeconomic strategies for education and social capital may promote or restrict, as appropriate, the emergence and/or strengthening of the position of any company in a market. The ideal situation which may tend to be, we believe, is that the state gradually builds social capital consisting of formal/informal relations between groups and organizations that support the creation of new knowledge. So, theoretically efficient firms should constitute alliances/strategic partnerships ("holonic network" type) to share common knowledge in a particular field and be of benefit to joint customers (ideal is when companies cooperate in a competitive context and aim to build a moral capitalism).

\section{Concluding Remarks}

There are many studies on the importance and/or role of knowledge in the functioning and progress of the modern capitalist state and on the performance that business organizations can obtain in different markets. Also, in the sense relied on, the term knowledge is advanced by some theorists to explain the mechanism by which countries / companies manage to achieve competitive advantage globally. On the other hand, the acquisition and exploitation of knowledge as a resource by separate firms will always be dependent, we believe, on the mechanism of thought and values of employees in which they believe. In other words, the notion of knowledge remains quite fluid, unclear and, consequently, difficult to define and include in the structure of a theoretical model. Various theoretical studies on the firm argue quite pertinently, we believe, the idea that a modern company remains directly/indirectly subject to exploitation of this resource called knowledge, so as to satisfy a number of customers and obtain profit. From this perspective, our study suggests only a general framework to link the known issues from the theory of the firm from a macroeconomic and microeconomic perspective.

\section{References}

1. Anderson, S. et al. (2002), Business: The Ultimate Resource, Bloomsbury Publishing Plc, London.

2. Burciu, A. (1999), MBO \& Ciclul afacerilor, Editura Economică, Bucureşti.

3. Coase, R. H. (1937), 'The Nature of the Firm', Economica 4, 386-405.

4. de Geus, A. (1999), The Living Company, Nicholas Brealey Publishing, London.

5. Drucker, P. (1946), Concept of the Corporation, John Day Company, New York.

6. Drucker, P. (1954), The Practice of Management, Harper \& Brothers, New York.

7. Drucker, P. (2001), The Essential Drucker. Harper Collins Publishers, New York.

8. Drucker, P. (2002), Managing in the Next Society, St. Martin's Press, New York.

9. Drucker, P. (2008), Management, Revised Edition, Harper Collins Publishers, New York.

10. Galbraith, K. (1992), The Culture of Contentment, Houghton Mifflin, Boston and New York.

11. Grant, R. M. (1996), 'Toward a Knowledge-Based Theory of the Firm', Strategic Management Journal 17, 109-122. 
12. Hammer, M. and Champy, J. (1993), Reengineering the Corporation, Harper Business, USA.

13. Hay, D. A. and Morris, D. J. (1986), Industrial Economics. Theory and Evidence, 6th edition, Oxford University Press, Oxford.

14. Hayek, F. A. (1933), Monetary Theory and the Trade Cycle, [Online], [Retrieved December 10, 2014] http://mises.org.

15. Hitt, M. A. and Ireland, R. D. (2005), Entrepreneurship, in: Cooper, C. (ed.), The Blackwell Encyclopedia of Management 2nd edition, Blackwell Publishing, USA.

16. Keynes, J. M. (1973), The General Theory of Employment, Interest and Money, Macmillan for the Royal Economic Society, London.

17. Keynes, J. M. (2009), Teoria generală a folosirii forței de muncă, a dobânzii și a banilor, Editura Publica, București.

18. Kirsimarja, B. and Aino, K. (2015),'Knowledge-based view of the firm: theoretical notions and implications for Management', [Online], [Retrieved March 21, 2015], http://www.lut.fi/documents/10633/109 602/tijo-valintakoeartikkeli-2015.pdf.

19. Kotler, P. and Caslione, J. A. (2009), Chaotics. Management şi marketing în era turbulenţelor, Editura Publica, București.

20. Krugman, P. (2009), The Return of Depression Economics and the Crisis of 2008, W. W. Norton \& Co, New York.

21. Lipsey, R., Steiner, P. O., Purvis, D. D. and Courant, P. N. (1990), Economics, Longman Higher Education, London.

22. Mc.Hugh, P., Giorgio, M. and Wheeler, W. (1995), Beyond Business Process Reengineering - Towards the Holonic Enterprise, John Wiley \& Sons Ltd, UK.

23. Nonaka, I. and Toyama, R. (2002),'A firm as a dialectical being: towards a dynamic theory of a firm', Industrial and Corporate Change 11(2), 995-1009.

24. Nonaka, I. and Toyama, R. (2005),"The theory of knowledge-creating firm: subjectivity, objectivity and synthesis", Industrial and Corporate Change 14(3), 419-436

25. Nonaka, I., Toyama, R. and Nagata, A. (2000), 'A firm as a knowledge- creating entity: a new perspective on the theory of the firm', Industrial and Corporate Change 9(1), 1-20.

26. OECD (2014), Entrepreneurship at a Glance, OECD Publishing, [Online], [Retrieved May 11, 2015], http://dx.doi.org/10.1787/entrepreneur_a ag-2014-en.

27. Peters, T. and Waterman, R. (1982), In Search of Excellence, Harper \& Row, New York.

28. Roubini, N. (2011), Crisis economics, Penguin Group, UK.

29. Senge, P. (2006), The fifth discipline, Random House Inc, London.

30. Smith, A. (1962), Avuţia naţiunilor, Cercetare asupra naturii şi cauzelor ei, Editura Academiei RPR, București.

31. Tacu, A. P., Vancea, R., Holban, Ș. and Burciu, A. (1998), Inteligența artificială. Teorie şi aplicaţii în economie, Editura Economică, București.

32. Williamson, O. (2010),'Transaction Cost Economics: The Natural Progression', American Economic Review 100, 673-690.

33. Young, S. (2003), Moral Capitalism: Reconciling Private Interest with the Public Good, Berrett-Koehler Publishers, San Francisco. 